\title{
ESPAÇOS DE MISERICÓRDIA EM SÃO PAULO: ANCESTRALIDADE
}

\author{
Maria Candelária V. Moraes ${ }^{1}$ \\ Sandra Regina Colucci ${ }^{2}$
}

\begin{abstract}
Articular historicamente algo passado não significa reconhecê-lo como ele efetivamente foi. Significa captar uma lembrança como ela fulgura num instante de perigo. ${ }^{l}$
\end{abstract}

\section{Resumo:}

Este artigo trata de práticas de caridade associada à questão do abandono de crianças, e neste sentido das intervenções nas relações entre mães e filhos, principalmente aquelas promovidas pelas Santas Casas de Misericórdia. A Santa Casa de São Paulo, de acordo com seus princípios de misericórdia, instalou em 1825 uma Roda para Enjeitados, que aos poucos passou a ser identificada como espaço de infantes perigosos, e não mais como de infantes em perigo. O Estado passaria a ter a tutela dessas crianças considerando que elas estariam "sob o efeito da ausência dos pais".

Palavras-chave: Caridade. Santas Casas de Misericórdia. Crianças abandonadas.

\section{Abstract:}

This article discusses the practices of charity associated with the matter of child abandonment, and in this sense the intervention in the relationships between mothers and children, especially those promoted by the Santa Casa de Misericórdia. A Santa Casa de São Paulo, in accordance with its principles of mercy, introduced a Baby Hatch in 1825, that was gradually known as a local for dangerous infants, and no longer for infants in danger. The State would be awarded custody of these children considering that they would be "under the effect of the parents' absence".

Keywords: Charity. Santas Casas de Misericórdia. Abandoned Children.

A questão do abandono de crianças vem neste artigo associada às práticas de caridade, proteção e de assistência construídas ao longo do tempo, primeiramente no velho mundo e depois, transplantado e estabelecido no Brasil, desde os primórdios da colonização. $^{2}$

Nesse sentido, as intervenções nas relações entre mães e filhos, por razões diversas - caridade, filantropia ou humanitarismo $-{ }^{3}$ têm ancestralidade secular, sendo que no século XVIII, uma menina em idade próxima a puberdade que perdesse o pai tinha grandes chances de ser enviada a um dos recolhimentos de órfãs administrados pelas Santas Casas da Misericórdia nos dois lados do Atlântico, pois a prática do recolhimento

\footnotetext{
${ }^{1}$ Mestre em História pela PUCSP. Professora do curso de História e de Arqueologia da UNIMES. Coordenadora dos cursos de História, Arqueologia e Geografia da UNIMES.

${ }^{2}$ Doutora em História pela PUCSP. Professora do curso lato senso de História da PUCSP e do curso de História da UNIMES.
} 
de mulheres em instituições de reclusão, tanto leigas quanto religiosas, não era novidade para essas sociedades, sendo que desde pelo menos a Idade Média mulheres em diversas fases do ciclo de vida eram recolhidas em conventos na qualidade de religiosas, noviças, educandas ou pensionistas. ${ }^{4}$

Nos tempos que se seguiram houve uma ampliação da prática da reclusão de mulheres e a proliferação de instituições leigas voltadas para o abrigo delas, especialmente órfãs, viúvas e outras desprovidas de tutela masculina. ${ }^{5}$

Destacando-se as obras que foram criadas para dar assistência social aos problemas por elas visados, como os da infância, consta, conforme seu livro de atas mais antigo datado de $1703,{ }^{6}$ a Santa Casa de São Paulo da Irmandade das Misericórdias, que eram irmandades leigas e que já existia antes de 1680, e como enfermaria, somente a partir de 1715, em local ignorado.

O projeto foi inspirado na obra da Rainha Leonor de Lencastro ${ }^{7}$ fundadora da Santa Casa de Misericórdia de Lisboa, em 1498, ${ }^{8}$ para a prática e o exercício de quatorze obras de misericórdia, como um Compromisso da Misericórdia de Lisboa:

\section{Um programa de acção com estatuto evangélico, como foram as mesmas equacionadas nas palavras de Jesus.}

- Tive fome e deste-me de comer; - Tive sede e deste-me de beber; Estava nu e vestistes-me; - Andava errante e acolheste-me; - Estava doente e visitastes-me; - Estava prisioneiro e libertaste-me; - Morri e deste-me sepultura;

Estas as obras de misericórdia ditas Corporais.

As espirituais enunciam-se assim:

- Dar bom conselho a quem pede; - Ensinar os ignorantes; - Corrigir os que erram; - Consolar os que estão tristes; - Perdoar as injúrias; Suportar com paciência as fraquezas do nosso próximo; - Rogar a Deus pelos vivos e pelos defuntos. ${ }^{9}$

O compromisso da Irmandade de São Paulo conservou o mesmo significado de caridade e piedade, sendo que não apenas a Santa Casa se inspirou nos moldes da de Lisboa, mas todas as demais que se criaram no país - por volta de dezesseis até 1750 também o foram, entendendo que "a luta contra a pobreza, a miséria moral e intelectual, a doença, a morte é uma questão recorrente na história da humanidade (...)."10

No Brasil, a cidade de São Paulo não teria sido a primeira a abrigar necessitados ${ }^{11}$, sendo Braz Cubas, fundador da Casa de Misericórdia de Santos em 1543, (donde viria o nome da cidade que a viu nascer) pioneiro a socorrer todos os necessitados de qualquer procedência que chegassem ao porto precisando de abrigo e tratamento de enfermidades.

O hospital surgiu um século depois (mais ou menos junto com São Paulo) ${ }^{12}$ mas, o primeiro Hospital de Misericórdia teria sido fundado no Rio de Janeiro pelo jesuíta José de Anchieta em 1582, que teria recebido numa casa doentes da armada de Diogo Baldez. ${ }^{13}$

Em 1741, vinte e seis anos depois de instalada a primeira enfermaria da Santa Casa em São Paulo, a Irmandade instalou o hospital junto à Igreja no Largo da Misericórdia, ${ }^{14}$ sendo que quatro casas de morada foram adquiridas para isso. A 
permanência do hospital foi muito irregular até 1801, ocupando-se uma ou duas casas, ora com a Cadeia Pública, ora com as enfermarias de Regimentos. De 1801 em diante passou a ocupar mais duas outras casas que faziam esquina com a Rua Direita então Rua da Misericórdia. Foi com a Santa Casa que se iniciou a assistência aos inválidos, aos encarcerados, aos lázaros e à infância.

Entre 1824 e 1825, na antiga Chácara Nossa Senhora da Glória localizada além da Chácara dos Ingleses, ao sul da Sé e no caminho do Ipiranga (que era limitada pelos rios Tamanduateí, Cambuci e Ipiranga, correspondendo em 1940, ao trecho entre as ruas Clímaco Barbosa e Major José Bento, e algumas quadras além do Largo do Cambuci, portanto, nas proximidades do antigo Caminho do Mar, ligando São Paulo a Santos, hoje Rua da Gloria, também conhecida como antiga Rua do Cemitério), o governo provincial instalou o "Seminário da Glória" para abrigar meninas órfãs.

Outra parte da chácara foi comprada por 3:000\$000 para instalar o Hospital da Santa Casa, ${ }^{15}$ sendo que só em 1872, passou a ter gás e água encanada por iniciativa do provedor Antonio da Silva Prado (Barão de Iguape) e do primeiro médico da Santa Casa, doutor Antonio Caetano de Campos. Em 1884, a Santa Casa foi transferida para a Chácara do Dr. Rego Freitas no bairro do Arouche.

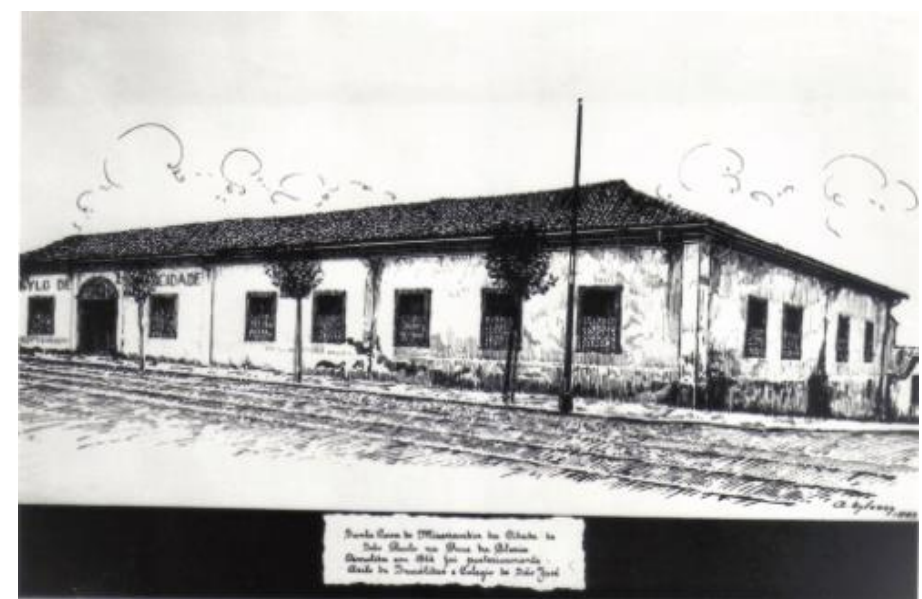

Fonte: Acervo do Arquivo de Negativos, DIM, DPH, SMC, da Prefeitura da Cidade de São Paulo.

Imagem 1 - Sede do hospital da Santa Casa na futura Rua da Glória, inaugurado em 1840, segundo planta do engenheiro português Marechal Daniel Pedro Müller (c. 1785-1841). Bico de pena de Augusto Esteves, 1943.

De acordo com seus princípios de misericórdia em dois de julho de 1825 , foi instalada a roda dos enjeitados numa janela do andar térreo do velho casarão, que recebeu a primeira criança dois dias depois, transformando-se com o tempo em problema social pela construção da noção de infância perigosa que marcaria as diferentes estratégias de controle do aparato assistencial às crianças ${ }^{16}$.

De acordo com Venâncio muitas mulheres viram-se diante da necessidade de abandonar os próprios filhos, sendo que, neste sentido "a história do abandono de crianças é a história secreta da dor feminina, principalmente da dor compartilhada por mulheres que enfrentavam obstáculos intransponíveis ao tentar assumir e sustentar os 
filhos", ${ }^{17}$ podendo, por consequência, o abandono ser interpretado como uma forma paradoxal de amor.

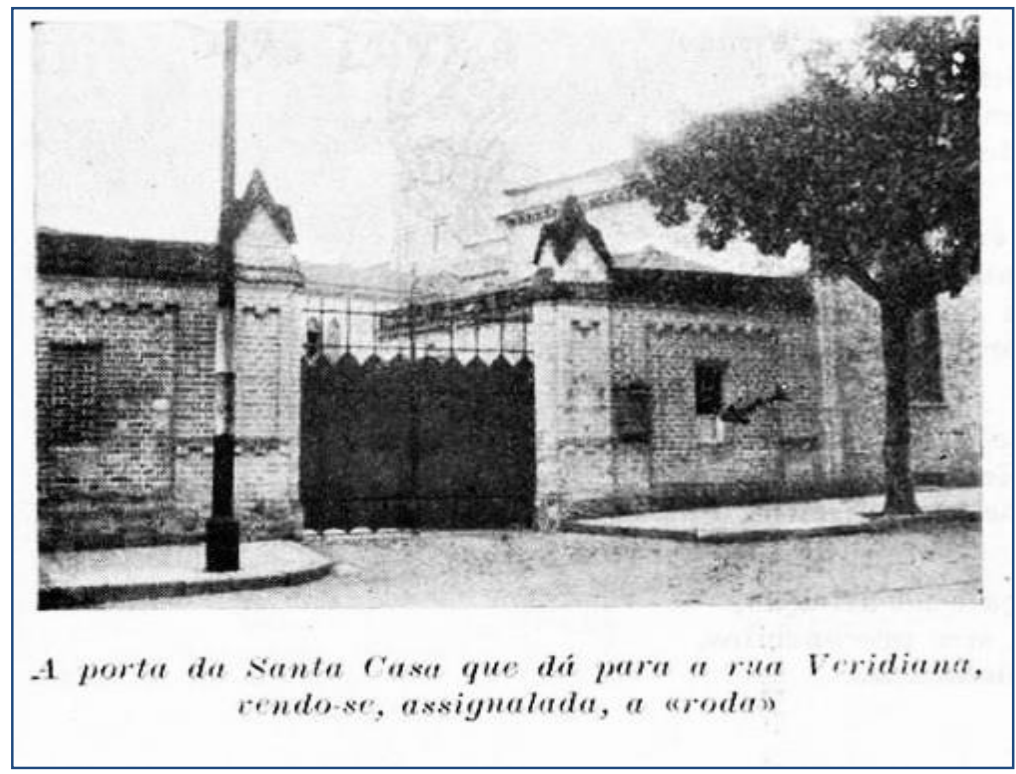

Fonte: Disponível em:<https://sampahistorica.wordpress.com/tag/roda-dos-expostos/>. Acesso em 16 março 2015.

Imagem 2 - Janela da Roda dos enjeitados da Santa Casa de São Paulo, na rua D. Veridiana. 


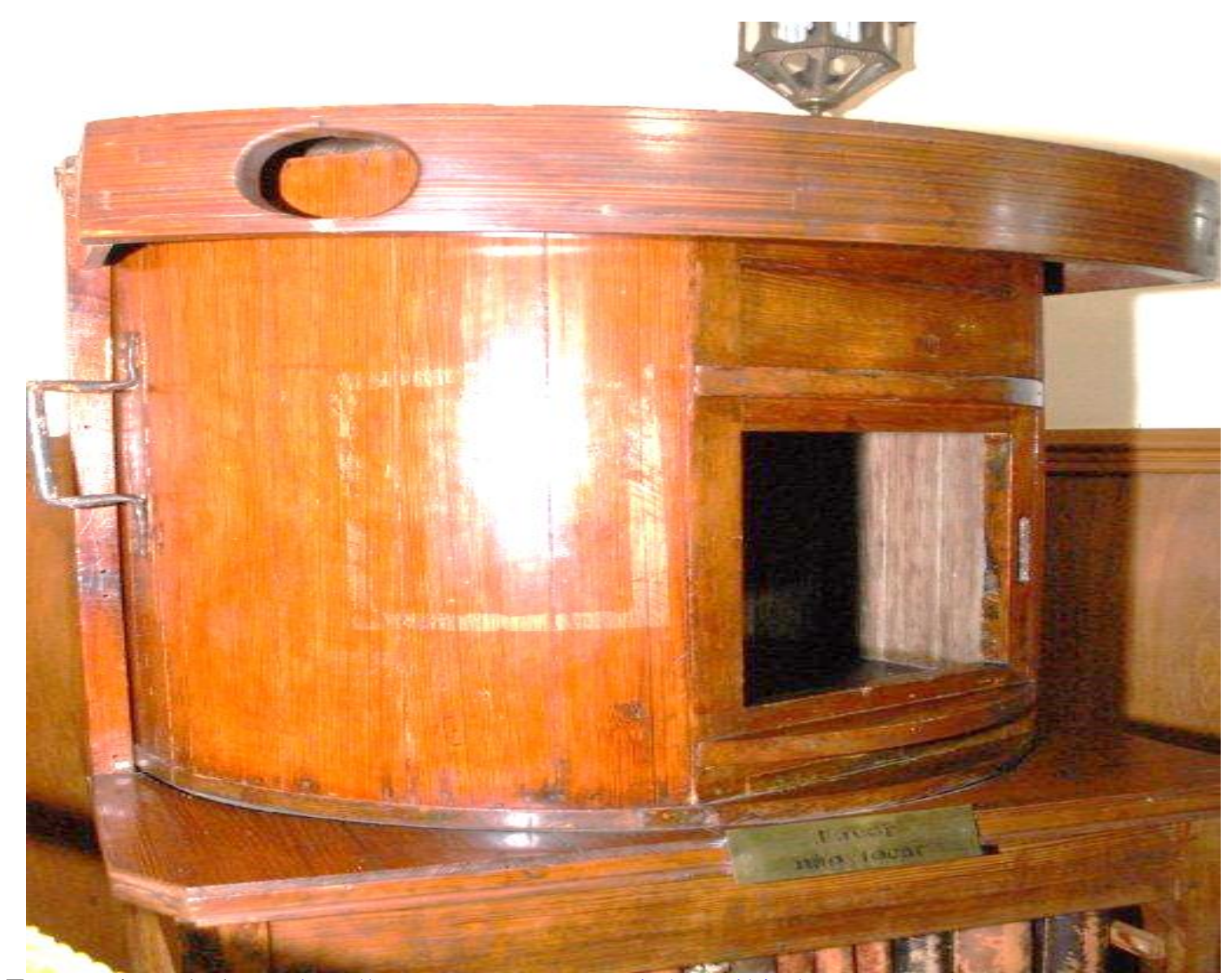

Fonte: Disponível em:<http://www.santacasasp.org.br/portal/site/quemsomos/museu>. Acesso em: 16 $\underline{\operatorname{março} 2015}$

Imagem 3 - Roda dos enjeitados da Santa Casa de S.P.

Colocava-se a criança no interior desse cilindro; este era girado de 180 graus, passando, então, a abertura do cilindro para o interior do prédio. O entregador tocava uma campainha que soava no dormitório das freiras e uma delas, então, recolhia a criança, providenciando sua internação. ${ }^{18}$

Essa região da Chácara da Glória onde se instalou primeiramente a Santa Casa de São Paulo guarda a memória de um período da história da cidade anterior a sua explosão urbana, marcada pela presença da morte, abandono e sofrimento: Largo dos Enforcados (Largo da Liberdade), Igreja dos Enforcados, Igreja dos Aflitos e Cemitério dos Aflitos. A escolha do local para instalação das referidas instituições se deve ao fato da chácara estar até final do XIX situada nas bordas da cidade. ${ }^{19}$ 


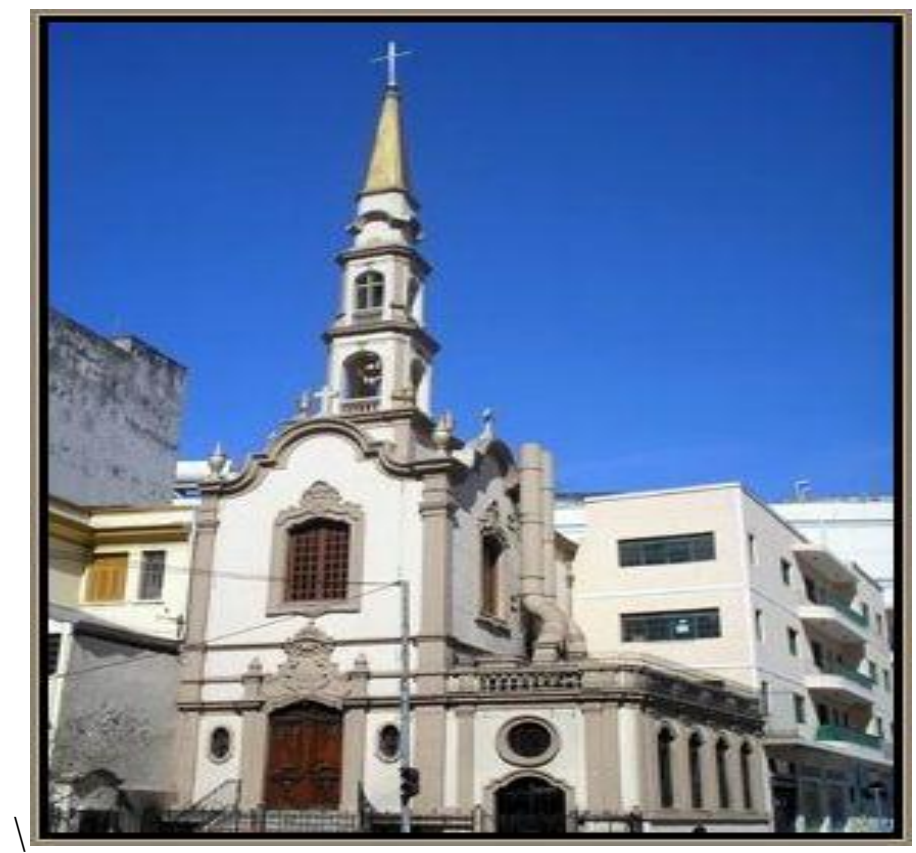

Fonte: Disponível em: $<5$ http://netleland.net/tag/igreja-santa-cruz-dos-enforcados $>$. Acesso em 12 março $\underline{2015}$.

Imagem 4 - Igreja da Santa Cruz das Almas dos Enforcados, na região da Chácara da Glória onde se instalou primeiramente a Santa Casa de São Paulo.

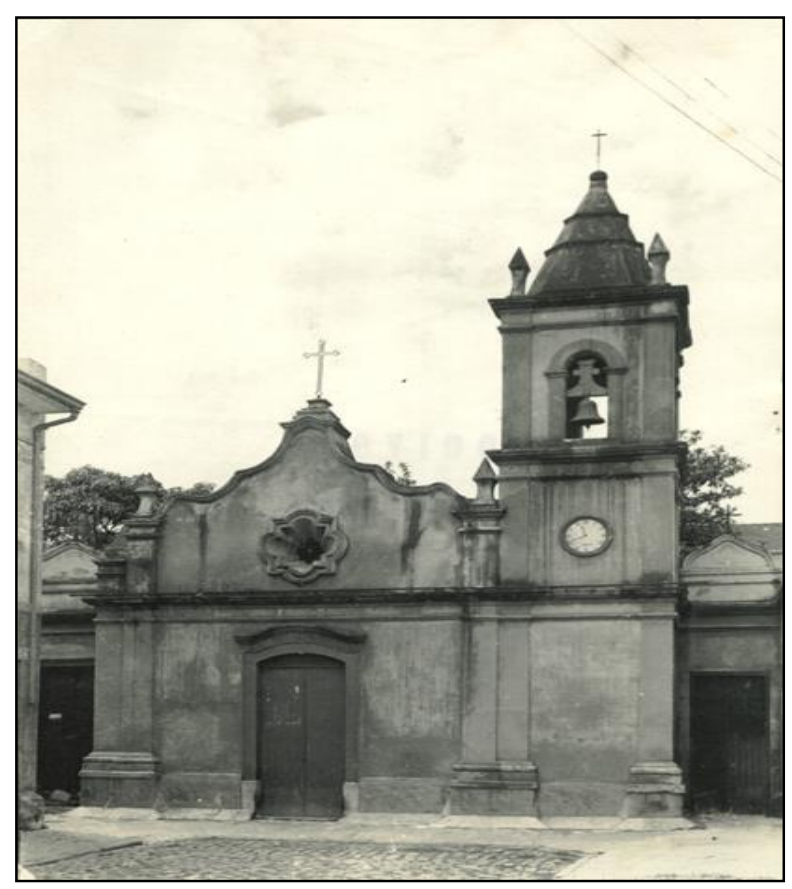

Fonte: 〈http://www.arquiamigos.org.br/info/info03/index.html〉. Acesso em 12 março 2015.

Imagem 5 - Capela dos Aflitos construída em cima do Cemitério dos Aflitos, primeiro cemitério de São Paulo para negros escravos, criminosos e pobres. 
A roda foi criada para recolher os enjeitados que até então eram deixados na porta de particulares, ${ }^{20}$ porém este abandono era seguido "à morte quasi imediata na grande maioria dos casos," ${ }^{21}$ pois, num período de seis anos, entre quatro de julho de 1825 e cinco de maio de 1831, dos cento e nove menores deixados na roda sessenta morreram.

A explicação dada para tantas mortes foi que a grande maioria dos enjeitados era deixada aos cuidados de amas ou criadeiras, que seriam "mulheres de origem modesta, as quais, residindo nas vilas mais pobres dos arredores da Capital (...), não visavam senão uma remuneração por pequena que fosse" 22 , significando que permaneciam na casa dos expostos apenas de 5\% a 10\% das crianças, servindo essas "amas criadeiras", como eram chamadas, "tanto as mães de família como as instituições públicas. Como não havia orfanatos suficientes para abrigar crianças abandonadas, a própria Santa Casa se utilizava de seus serviços." 23

De acordo com Kuhlmann e Rocha, "em 1909, de cento e vinte e seis crianças entregues às amas de sítios, vinte e duas faleceram. De vinte e cinco aos cuidados das amas da cidade, doze morreram (...), é elevadíssima a mortalidade - 50\%" ${ }^{24}$. Estes altos índices permaneceram constantes sendo atribuídos às condições de higiene e moradia das amas, conforme afirmava em 1936, o então mordomo da Santa Casa Guilherme Dumont Villares:

[...] as criadeiras ou amas que assim se chamavam, eram mulheres de origem modesta, as quaes, residindo nas vilas mais pobres dos arredores da Capital, ao receber a creança em sua casa, não visavam senão uma remuneração, por pequena que fosse. E era, de facto, das mais modestas a que a nossa Instituição lhes dava por tal serviço [...]. Nessas condições, é bem de ver-se, havia de ser das mais rudimentares a assistência que taes "amas" poderiam prestar as creanças que perfilhavam [...]. Assim, por mais que fosse a bôa vontade que algumas revelavam, a precariedade das condições materiais impossibilitava uma conveniente assistência á creança exposta, que em geral pagava com a vida a ausência das atenções com que a moderna pediatria consegue, em certos paizes, reduzir a um mínimo a cifra da mortalidade infantil. ${ }^{25}$

Apesar da denúncia da falta de condições materiais das amas, as crianças que sobreviviam continuavam com estas, e atingida a idade escolar eram levadas ao Seminário da Glória se fossem meninas ou para o Seminário de Sant 'Ana se fossem meninos.

No entanto, como não havia vagas para todas as crianças, a Santa Casa nomeou uma comissão que aprovou a sugestão de se confiarem os menores ao Juiz de Órfãos, que lhes indicaria um tutor. Pelo Código de Menores de 1927, as rodas foram abolidas, mas até 1940 , segundo Ferreira, continuavam a ser usadas. ${ }^{26}$

\section{Estabelecimentos pios de São Paulo}

De acordo com o Visconde de Congonhas ${ }^{27}$, presidente da província de São Paulo, em 1825 a cidade de São Paulo registrava o "maior número de infelizes menores órfãos brancos, reduzidos ao mísero estado de indigência e mendicidade," 28 afirmando que:

Há pelas ruas meninos quasi nus tremendo de frio, e mendigando o sustento. Muitos vivem nas senzalas, a habituar-se com os máus 
costumes dos pretos, a servir às mulheres "que os criarão aos seus peitos". Meninas há as que se prostituem, pela miséria, exploradas pelas suas antigas amas! $!^{29}$.

Diante desse quadro que evidencia as sociabilidades estabelecidas pelos populares e o tratamento sofrido pelos negros, percebe-se a permanência dos discursos sobre o abandono das crianças, sendo que desde 20 de outubro de 1823, o presidente e também provedor da Santa Casa, Visconde de Congonhas, fundara quatro Estabelecimentos Pios em São Paulo: os colégios de Santana e da Glória, para a infância órfã e pobre; o Hospital de Caridade, da Irmandade de Santa Casa de Misericórdia, e a Casa dos Expostos e Roda dos Enjeitados.

O Seminário das Educandas da Glória para meninas órfãs e pobres, chamado Seminário de Meninas Órfãs e Educandas da Glória ou Seminário da Glória, foi destinado "principalmente para filhos de militares que serviram a Pátria (Guerra do Paraguai) e morreram indigentes." 30

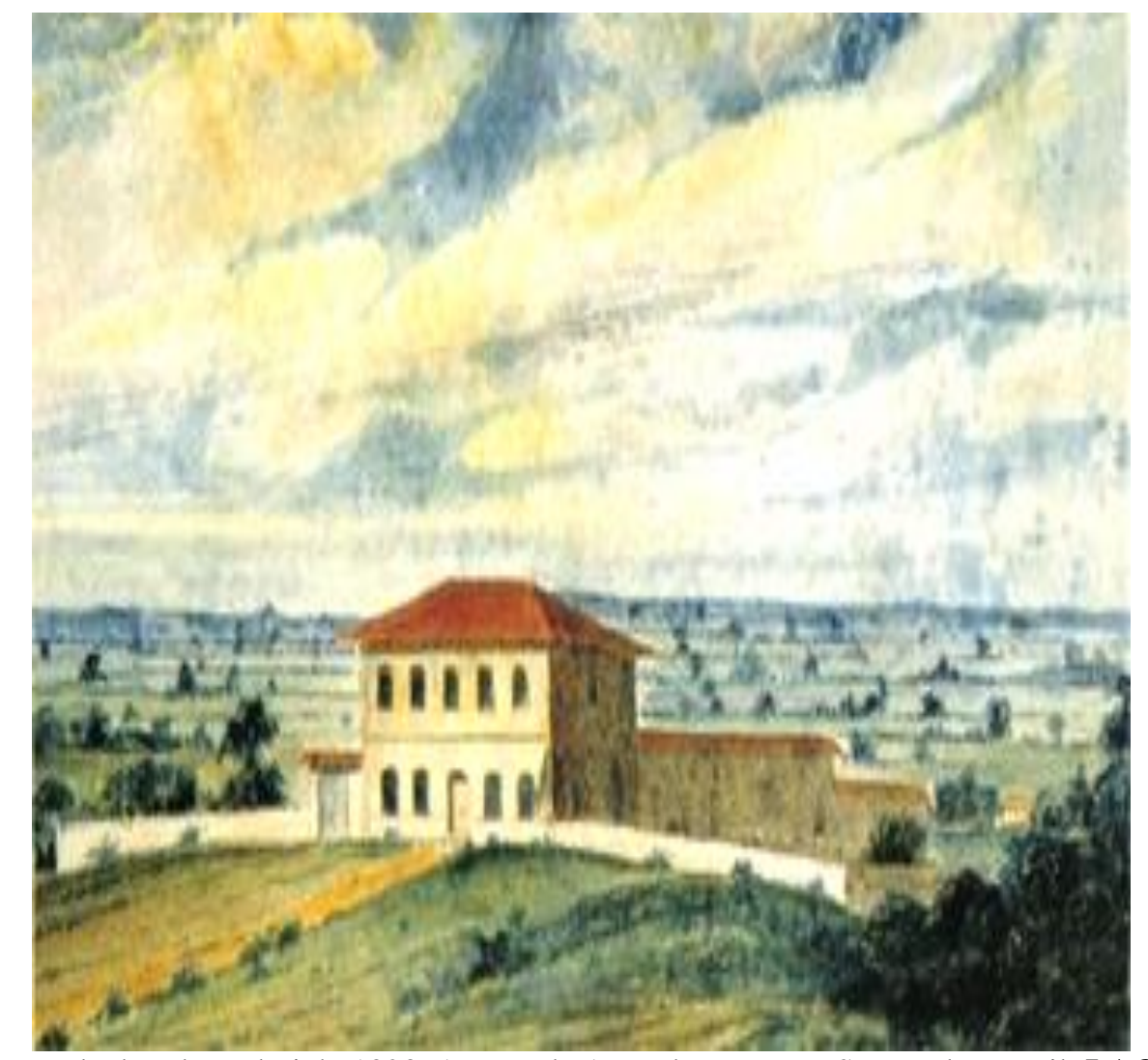

Fonte: Aquarela de Edmond Pink, 1823. Acervo de Artes da Bovespa, São Paulo, Brasil. LAGO, Pedro Correa do. Iconografia Paulistana no século XIX. São Paulo: Metalivros, 1998.

Imagem 6 - Sede da Chácara dos Ingleses, onde, a partir de 1825, funcionaram o Hospital da Santa Casa e o Seminário da Gloria.

O seminário foi instalado em 1825, na antiga Chácara dos Ingleses, que era propriedade da Fazenda Nacional, por ter sido considerado que lá havia "bôas casas, 
capella e terras próprias" ${ }^{31}$, e recebeu uma dotação, feita pelo imperador Dom Pedro I, de $600 \$ 000$ anuais.

O governo da Província nomeou como diretora interina a portuguesa Elisiaria Spínola, e como administrador externo seu pai, tendo sido "dois escravos e duas escravas da Nação postos a serviço do estabelecimento, nele tendo morada obrigatória". ${ }^{32}$

Apesar dessas providências, em 1833, o seminário que passava por dificuldades financeiras foi transferido para o edifício onde funcionara o hospital militar e quartel do $7^{\circ}$ batalhão no Beco do Sapo, ou também Beco do Acú, que a partir de 1856, passou a ser chamado de Rua do Seminário. Em 1861, o Seminário foi transferido para a Chácara do Fonseca, no fim da Ladeira do Tabatinguera, onde entre 1859 e 1861 também esteve o Seminário Santana.

Em fins de 1833, era referida a precariedade das instalações da Chácara da Glória, onde os canos de água da cozinha e do tanque de roupas estavam arrebentados; faltavam bancos na sala de escrever, de modo que as meninas trabalhavam em pé, apoiadas em uma grande mesa; os dormitórios eram muito pequenos, o que obrigava as educandas a dormirem aos pares na mesma cama.

Não se conhecem os motivos exatos para essa situação, mas uma das explicações pode ser o fato de que os diretores do Seminário o administravam como coisa privada. Talvez essa miséria cotidiana tivesse a ver com o componente religioso e ascético da devoção beata, popular, reprimido pelo governo ilustrado. ${ }^{33}$

Um ano depois o prédio foi comprado pela Assembleia Legislativa para a instalação do Hospício dos Alienados, obrigando o Seminário a retornar em 1862, ao casarão do Beco do Sapo onde permaneceu até 1895, quando foi transferido para outro prédio localizado entre a Rua Brigadeiro Tobias e a Ladeira Santa Efigênia, que pertencera a Marquesa de Santos. Em 1898, foi transferido mais uma vez para a Chácara de Veridiana da Silva Prado ${ }^{34}$, que foi comprada pelo governo para este fim.

No Seminário da Glória as meninas eram admitidas com o mínimo de seis anos e o máximo de quinze, porém registrava-se que estava sempre superlotado, sendo que nos quartos para dez meninas encontravam-se vinte e oito, a maioria com doze anos.

A situação geral das obras sociais submetida à burocracia das resoluções do governo era carente de educadores para o ensino da aritmética, das primeiras letras, bordado e costura dados em uma única sala de aula com poucas mesas e bancos.

A partir de 1851, passaram a ser aceitas pensionistas menores cujos pais pudessem pagar $6 \$ 400$ mensais. Aos dezoito anos as expostas educadas no Seminário receberiam um dote para casamento, e não querendo se casar as jovens eram colocadas em "servidão", em casas de família. ${ }^{35}$

Essa instabilidade certamente teria constituído um impedimento para a regularidade da educação das internadas. Apesar da aplicação do lucro da loteria ${ }^{36}$ da província em benefícios das obras de caridade, as resoluções demoradas do governo fazia com que raramente o valor lhes fosse entregue. Buscando dar melhoramento à obra, em 1871, a Congregação francesa das Irmãs de São José de Chambery ${ }^{37}$ foi contratada para administrar o seminário, quando foi criado um regulamento nas seguintes bases: 
Instruir as órfãs no Catecismo, gramática portuguesa, História Sagrada, aritmética e geografia; ensinar a costurar, remendar, dar pontos de meia e todos os outros serviços de agulha; iniciá-las, em geral, em todas as prendas domésticas "da condição de órfãs." 38

A Congregação das Irmãs de São José de Chambery, fundada em Puy, na França em 15 de outubro de 1650, pelo padre Jean Pierre Medaille, sacerdote jesuíta, havia enviado freiras em 1858, para Itu, Estado de São Paulo para assumirem a Santa Casa de Misericórdia e abrirem o primeiro Colégio Feminino no Estado de São Paulo.

Em 1872, o Dr. Antônio da Silva Prado, Barão de Iguape, que era então o provedor da Santa Casa de Misericórdia, que se encontrava numa fase difícil por falta de pessoal habilitado ao trato de doentes e pela deficiente organização dos serviços que deveria prestar, pediu a vinda, da França, das Irmãs de São José de Chambéry.

O próprio Barão de Iguape custeou pessoalmente a viagem das cinco primeiras Irmãs da França que aqui chegaram e a elas foram confiados os pacientes a quem serviam como enfermeiras, na escrituração do hospital, na preparação das receitas e no cuidado com as refeições. ${ }^{39}$

Pondo em evidência que as lógicas da caridade dos doadores eram inerentes às práticas de caridade onde se inscreviam as Misericórdias, Isabel Sá refere que suas estratégias, enquanto membros de grupos de elite, seriam a pretendida pacificação de conflitos sociais sem colocar em causa a ordem existente, e a seleção de receptores de recursos com base em critérios morais disciplinadores. ${ }^{40}$ 


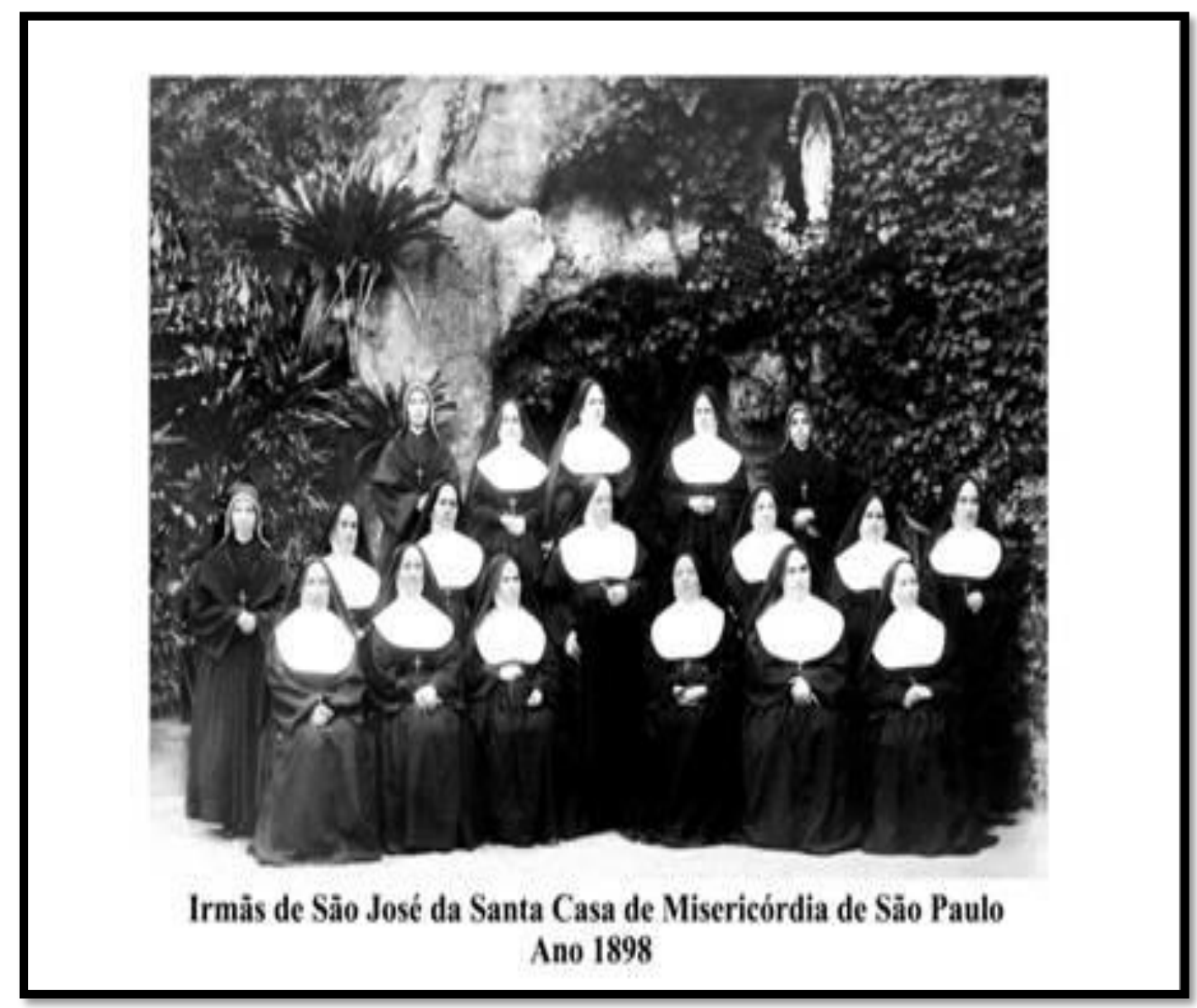

Fonte: Disponível em:<http://www.santacasasp.org.br/upSrv01/up_publicacoes /4639/5088_3453_MUSEU-HISTORICOS-AS-IRMAS-CHAMBERY.pdf>. Acesso em 1º junho 2015.

Imagem 7 - Irmãs de São José da Santa Casa de Misericórdia de São Paulo, 1898.

Pelas suas qualificações essas ordens religiosas, como as das irmãs de São José, dos beneditinos ou dos maristas vinham subsidiadas pelas elites proprietárias e fundaram 'prestigiosas' escolas, sendo que até 1880, o Seminário das Educandas da Glória foi o único internato destinado à educação de meninas na cidade de São Paulo. ${ }^{41}$

O Externato de São José foi criado em 1880, como obra especial da Santa Casa de Misericórdia, e destinou-se à educação de meninas filhas de famílias ricas sob a administração das irmãs de São José.

O externato foi instalado nas dependências do hospital, que na ocasião estava na Chácara dos Ingleses na Rua da Glória. Quando da transferência do hospital, em 1884, para o Bairro do Arouche, lá permaneceu o externato, que em 1920, registrou mais de mil alunas matriculadas.

O Seminário de Educandos de Sant'Ana foi criado na antiga fazenda Sant'Ana dos Jesuítas, confiscada pela Coroa quando da sua expulsão, em 1759. Surgiu juntamente com o Seminário Nossa Senhora da Glória, em $1825 .{ }^{42}$

O Seminário de Educandos de Sant'Ana foi um dos quatro estabelecimentos pios criados pelo Visconde de Congonhas, que estabelecido num prédio da Fazenda Nacional 
no "longínquo bairro de Sant'Ana em local distante a mais de meia légua da Igreja da Luz" 43 deveria ser dirigido pelo Frei Joaquim Francisco do Livramento, tendo por finalidade "sustentar, vestir e educar meninos órfãos e pobres". ${ }^{4}$

No entanto, a realidade era outra bem diferente, pois pela ausência constante do Frei, os cuidados da casa ficavam confiados a um menino de doze a treze anos, que como monitor se encarregava até das aulas das primeiras letras por meio da leitura de jornais.

Conforme relatório de 1845 , o presidente da província Lima e Silva, ${ }^{45}$ diante da "condição de miséria e digna de lastima desses infelises (...) mandou vestir decentemente os menores e reparar o predio" 46 , afirmando que:

A miséria enerva e abate o espírito e se a edade maior não vem depois com outros socorros quase sempre desfavoraveis impressões da infancia se conservão indeléveis e o abatimento de caracter e a anulação dos sentimentos nobres se consumam por toda a vida. O professor é incompetente e a leitura é ensinada por dois jornaisinhos da época, "Novo Farol" e "Paulista". ${ }^{47}$ Mesmo os leitos chegam a faltar. ${ }^{48}$

Assim, determinou que se criasse um regulamento com a indicação de um novo diretor, um mestre de primeiras letras que deveria morar no local, um capelão e serventes. A idade mínima para admissão no seminário foi fixada em seis anos, podendo o menino lá permanecer até completar quatorze anos.

O seminário passou então a receber expostos em idade escolar, órfãos de pai e mãe, e menores sem tutor ou parente responsável em estado de carência.

Em relação à disciplina, aparentemente os castigos físicos teriam sido abolidos, porém eram usados nos casos de faltas consideradas graves dos meninos, apontando para as estratégias pedagógicas de disciplinarização dos corpos na construção das sensibilidades daquelas crianças, quando então seria aplicada

a reclusão solitária por uma hora em local escuro, ficar sentado em 'banco do desprezo' em que esteja pintada a imagem de um burro desde uma hora até todo período escolar. ${ }^{49}$ Também foram usados como castigo trazer sobre o ventre e atado à cintura, com barbante, um papel com o letreiro em maiúscula - VADIO DESCUIDADO - DESORDEIRO - COMILÃO ou outra palavra que publique o vício, defeito ou culpa. ${ }^{50}$ Os egressos costumavam ser encaminhados para as oficinas da Real Fábrica de Ferro São João D'Ipanema ${ }^{51}$, que em 1810, criada por D. João VI, na então vila de Sorocaba foi a primeira siderúrgica brasileira, apresentando déficits contábeis durante toda sua existência necessitando, portanto, de mão de obra barata, facilmente retirada dos asilos.

Também os egressos eram enviados para Arsenais de Guerra e Marinha da Corte, pois que, de acordo com Londoño, a partir da discrepância de critérios, o discernimento e a suposta noção da diferença entre o bem e o mal atribuída às crianças, as transformava, em determinados momentos, em adultos, podendo responder ante a justiça, ou assumir responsabilidades, como no caso da incorporação ao Exército e à Armada ou ao Arsenal da Marinha. ${ }^{52}$ 


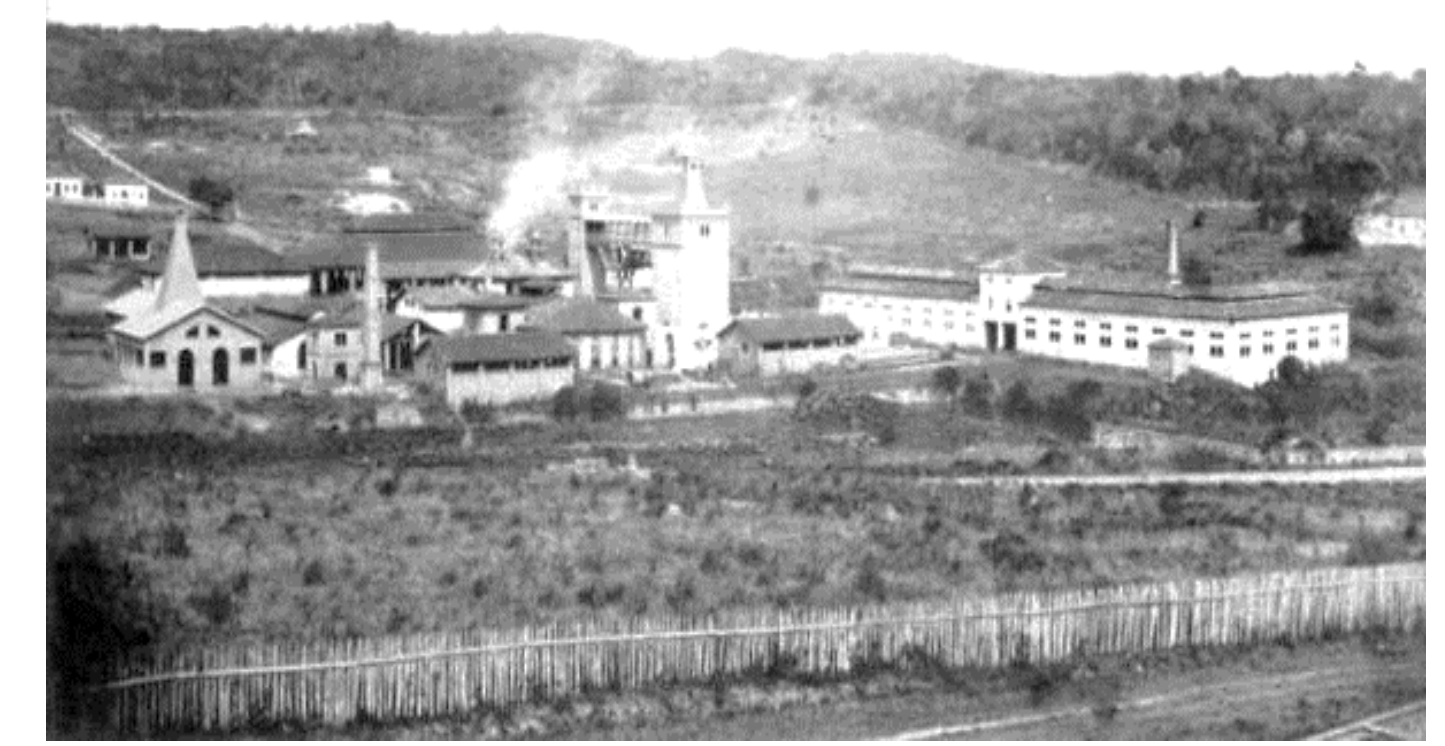

Fonte: Disponível em:<http://caminhodosul.blogspot.com.br/2012/04/real-fabrica-de-ferro-de-sao-joaodo.html>. Acesso em 13 abr. 2015.

Imagem 8 - Fábrica de Ferro São João D’Ipanema. s/d.

No entanto, até 1852 aquele regulamento não havia sido aplicado, fazendo com que o inspetor geral da Instrução Pública, que assumia naquele momento a direção do seminário, capitão Candido Caetano Moreira, sugerisse que as aulas fossem franqueadas aos meninos residentes no bairro. Diante da proposta o presidente da província, Nabuco $\mathrm{D}^{\prime}$ Araujo, ${ }^{53}$ aventou a criação de oficinas no seminário para aprendizado profissional com vistas a "dar aos menores garantias de subsistência futura." 54

Nesse sentido, em 1874, o seminário foi restaurado como Instituto de Artífices ou Escola de Educandos Artífices. No período republicano ele já não consta de nenhuma relação de estabelecimentos de educação de menores. É possível que a ele tenha sucedido o Instituto Disciplinar do Estado, depois Instituto Modelo de Menores.

Fundada por Carlos Leôncio da Silva Carvalho, em 14 de dezembro de 1873, e sob a presidência de Martim Francisco Ribeiro de Andrada, a Sociedade Propagadora da Instrução Popular teve seus estatutos aprovados em cinco de janeiro de 1874, pelo presidente da província João Teodoro Xavier de Matos. ${ }^{55}$

A Sociedade ofereceu matrícula gratuita para cem alunos no curso primário ministrado à noite, onde se ensinava aritmética, gramática portuguesa, caligrafia e sistema métrico. Em 1875 já contava com 442 alunos e, em 1882 mais de oitocentos alunos. ${ }^{56}$

Estimulada pelo movimento favorável à educação popular, que se manifestava na Escola de Educandos Artífices e no Colégio Dona Ana Rosa, a Sociedade Propagadora da Instrução Popular modificou sua escola para um tipo de Liceu profissional, Liceu de 
Artes e Ofícios, destinado a "ministrar gratuitamente ao povo os conhecimentos necessários ás artes e ofícios, ao comercio, á lavoura e ás industrias (...) para levantar o nível moral e intelectual das classes laboriosas". ${ }^{57}$ Foram professores do Liceu: Rangel Pestana, Galvão Bueno, Caetano de Campos, Vieira de Carvalho e outros nomes da elite paulista.

Necessitando cada vez de mais espaço foi transferido várias vezes: da Rua São José ${ }^{\circ}$ 5, hoje Rua Líbero Badaró, para a Rua do Imperador e depois para a Rua Santa Terêsa. Em 1896, passou para o prédio contíguo à Igreja dos Remédios em frente ao Largo Sete de Abril e Rua Onze de Agosto, de onde foi transferido para o lado do Jardim da Luz num grande edifício projetado por Ramos de Azevedo, hoje Pinacoteca do Estado de São Paulo.

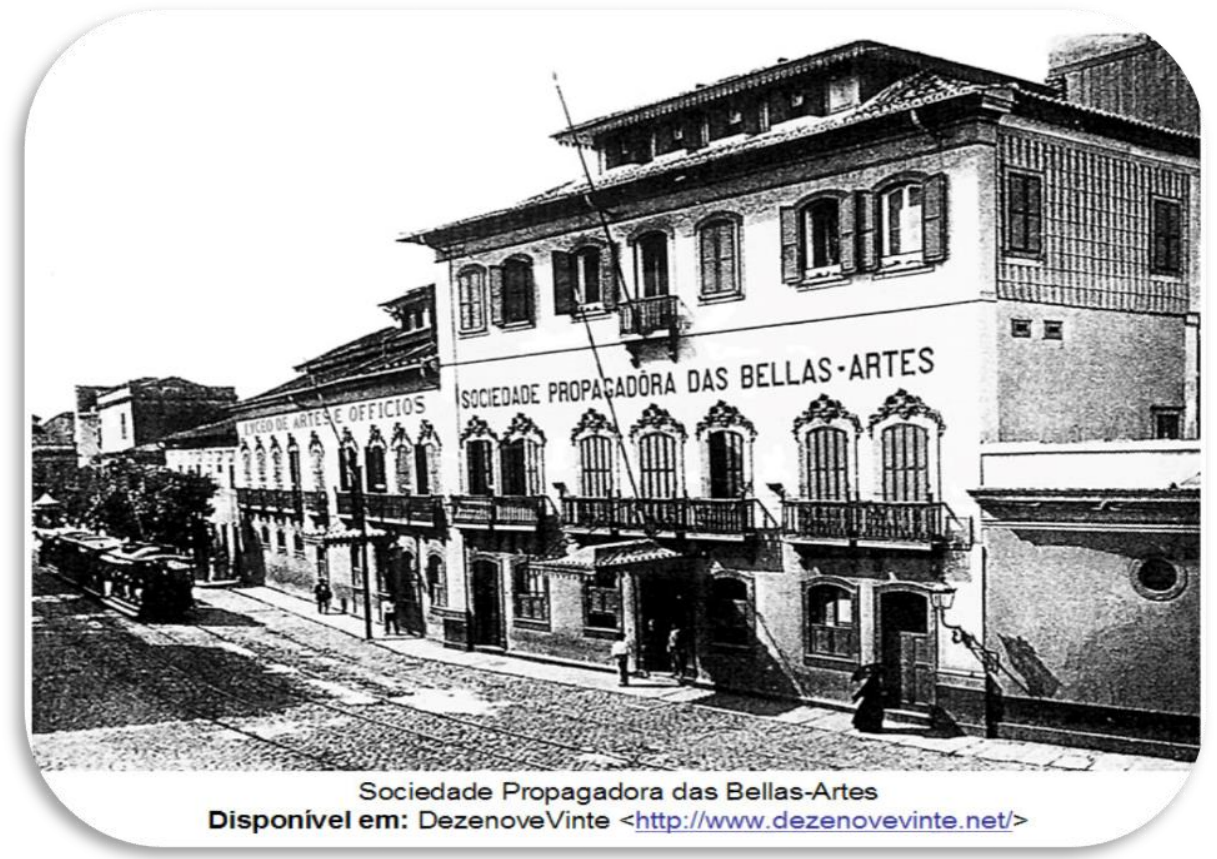

Fonte: Disponível em:<https://www.google.com.br/search?q=antigo+predio+do+liceu+de+ artes+e+oficios\&rlz=> Acesso em 25 maio 2015.

Imagem 9 - Sociedade Propagadora de Instrução Popular 


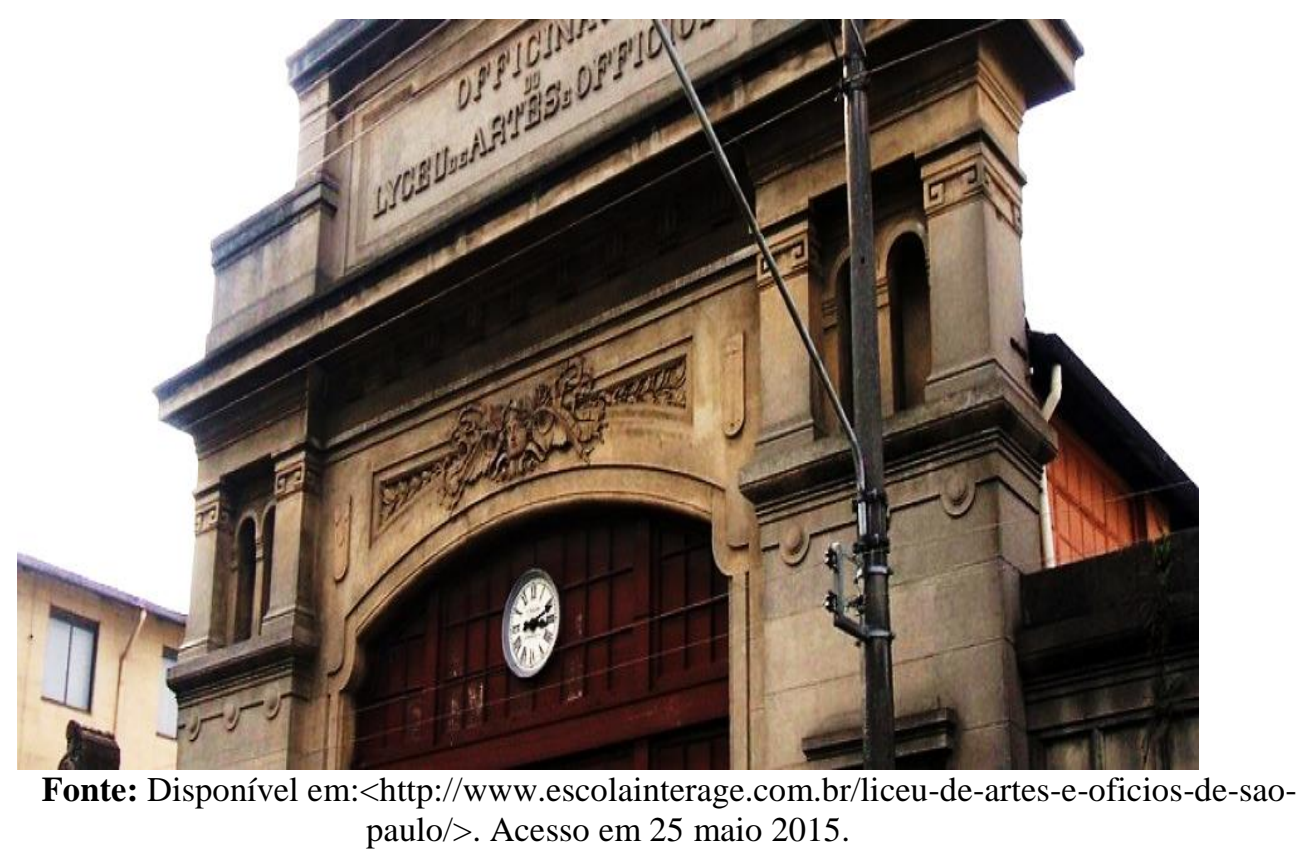

Imagem 10 - Liceu de Artes e Ofícios

O Asilo de Meninas Órfãs Desamparadas Nossa Senhora Auxiliadora, situado no bairro do Ipiranga, e que se tornou mais tarde a Fundação Nossa Senhora Auxiliadora (FUNSAI), ficava em prédio projetado por Ramos de Azevedo e foi inaugurado em 1896, pelo conde José Vicente de Azevedo, que também foi responsável pela construção do orfanato São Cristóvão. 


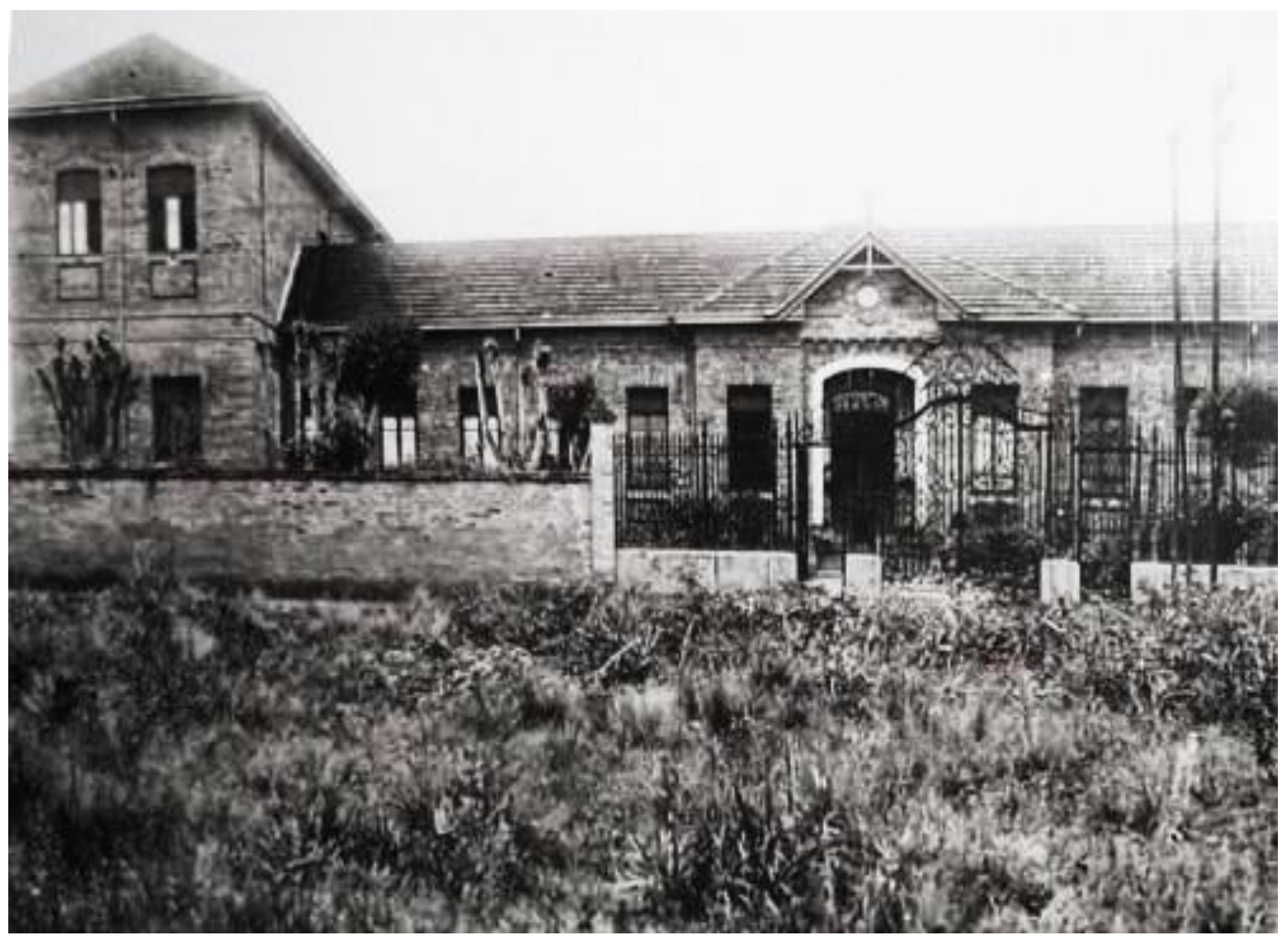

Fonte: Disponível em:<https://www.pinterest.com/pin/>. Acesso em 18 maio 2015

Imagem 11 - Asilo de Meninas Orfãs Desamparadas Nossa Senhora Auxiliadora.

Buscando apontar a interiorização desses modelos de estabelecimentos na região de Ribeirão Preto, foi produzido um quadro que enumera os diferentes institutos da cidade de São Paulo ficando evidente que comparando os exemplos provenientes do século XIX, é certo que a assistência privada oferecida ao público respondeu com maior número de estabelecimentos e iniciativas às demandas do amparo à doença, à pobreza, à instrução de meninos e meninas pobres e às crianças órfãs, quando comparada às ações estatais nessa mesma época. ${ }^{58}$ 


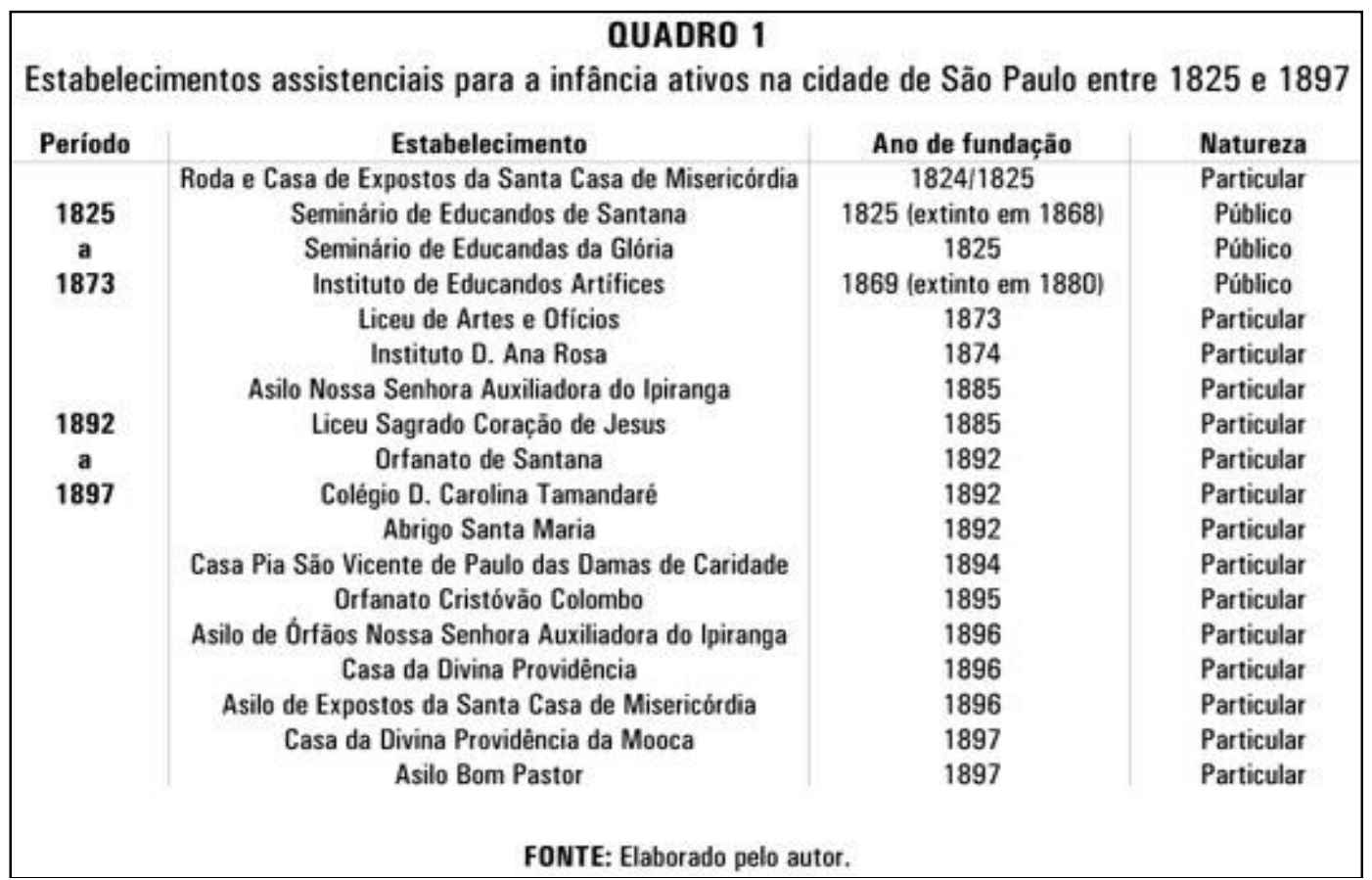

Fonte: FONSECA, Sérgio C.. A interiorização da assistência à infância durante a primeira república: de São Paulo a Ribeirão Preto. Educ. rev., Belo Horizonte, v. 28, n. 1, Mar. 2012. Available from <http://www.scielo.br/scielo.php?>. access on 03 Apr. 2015. Disponível em:〈http://dx.doi.org >.

O Instituto Ana Rosa foi destinado à formação profissional de menores do sexo masculino em regime de internato, como obra especial da Associação Barão de Souza Queiroz de Proteção à Infância e à Juventude fundada para manter o Instituto D. Ana Rosa, que surgiu em 1874, como Sociedade Protectora da Infância Desvalida - Instituto D. Ana Rosa. ${ }^{59}$

Os meninos órfãos recebiam instrução primária, preparo profissional e educação moral com o objetivo de que fossem "capazes de prover á própria existência mediante o exercício da ocupação honesta, tornando-se úteis e dignos cidadãos." 60 


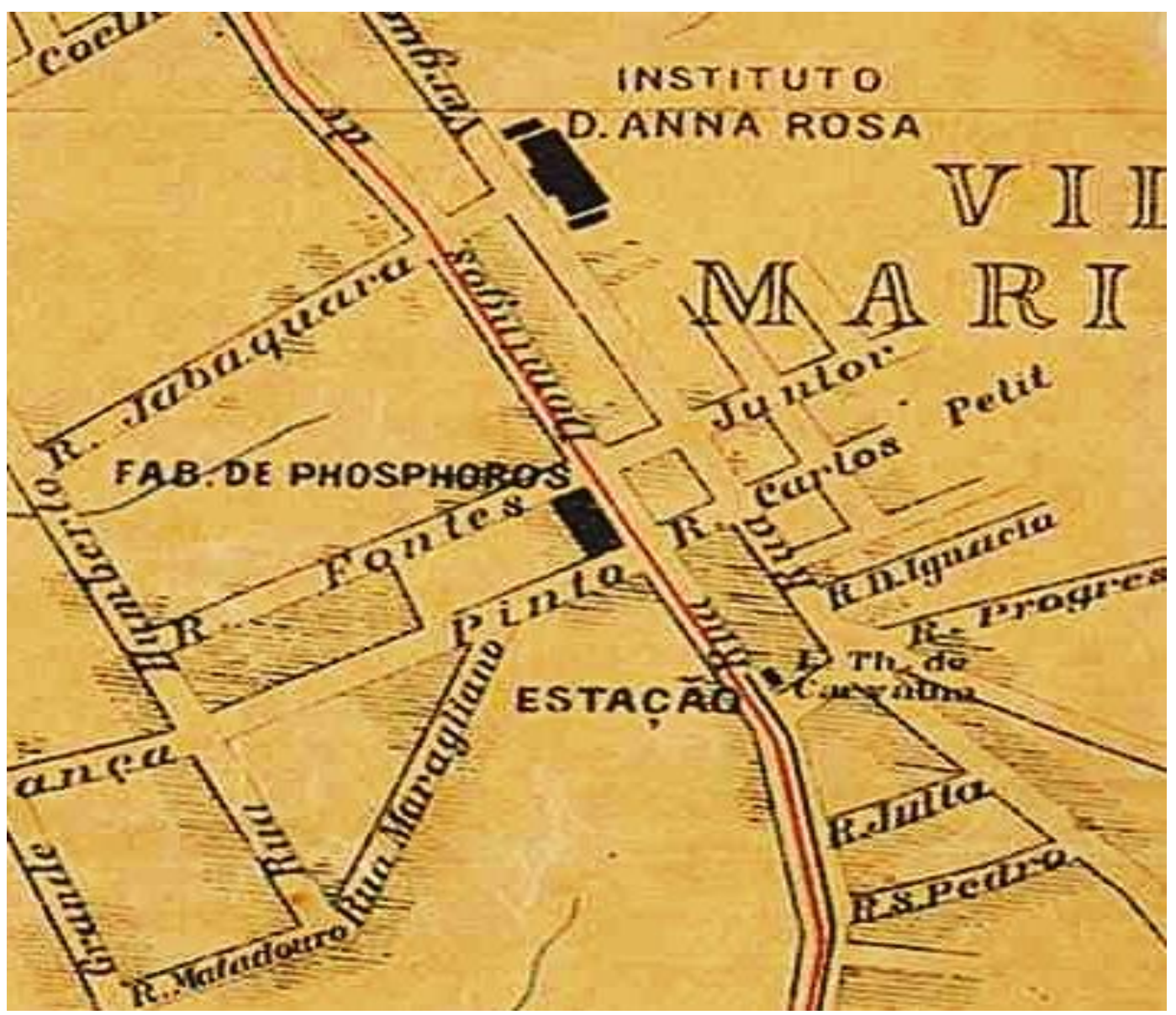

Fonte: Disponível em:<www.estacoesferroviarias.com.br>. Acesso em 26 maio 2015.

Imagem 12 - Localização Instituto Ana Rosa.

O Instituto que foi instalado na chácara do senador Queiróz ${ }^{61}$ (hoje bairro de Santa Ifigênia), estava localizado entre as ruas Brigadeiro Tobias, Travessa da Independência, Florêncio de Abreu e Washington Luís e foi deslocado para a Vila Mariana, em 1894, para a Rua Vergueiro.

Sendo o primeiro estabelecimento de ensino profissional de iniciativa particular de São Paulo (o primeiro instituto público foi o Instituto de Artífices - antigo Seminário dos Educandos de Sant'Ana), teve como sócios beneméritos o barão de Souza Queiroz, Dona Ana Rosa de Araújo e o segundo barão de Piracicaba, Rafael Tobias de Aguiar Pais de Barros, ${ }^{62}$ futuro sogro do presidente Washington Luís, portanto a elite paulistana. O nome do Instituto foi uma homenagem à Ana Rosa de Araújo ${ }^{63}$, que viúva e sem filhos deixou sua fortuna para obras de caridade.

Todas essas famílias - Antônio da Silva Prado (Barão de Iguape), os Souza Queiroz, os Araújo, os barões de Piracicaba (Pais de Barros), os Rangel Pestana, Galvão Bueno, Caetano de Campos, Vieira de Carvalho e outras - que em nome da caridade trabalharam em prol da construção de instituições para o abrigo de crianças abandonadas, constituíam a elite paulista e conforme Tânia Soares da Silva - que questionou as experiências e múltiplas estratégias dessas elites - estas pretendiam assegurar e 
estabelecer sua herança política, caso dos Paula Souza, ${ }^{64}$ pela "manutenção de sua influência nos mais diversos setores da vida": ${ }^{65}$

Notabiliza-se que os Paula Souza estão inscritos na história de São Paulo pela participação ativa na vida política da cidade e do país, mas entre eles dois nomes mantém seu lugar de memória encravado na cidade: Geraldo Horácio de Paula Souza(1889-1951), idealizador do Instituto de Hygiene de São Paulo, hoje Faculdade de Saúde Pública da Universidade de São Paulo; e Antonio Francisco de Paula Souza (18431917), idealizador do Instituto Politécnico[...]. ${ }^{66}$

$\mathrm{O}$ início do século XX foi marcado por uma série de questões que colocam a criança, em especial àquela oriunda das classes populares em evidência, ${ }^{67}$ pois que entendiam que "a criança bem educada seria preservada das rudezas e da imoralidade, que se tornariam traços específicos das camadas populares e dos moleques." 68

Pensada como um ser incompleto e insuficiente em relação ao ponto de chegada almejado, a vida adulta, a criança deveria ser regulada para o convívio social, fazendo surgir uma nova ordem de prioridades no atendimento social que ultrapassou o nível da filantropia privada e seus orfanatos, para elevá-la às dimensões de problema de Estado com políticas sociais e legislações específicas. ${ }^{69}$

A partir de então, na ordem de prioridades, novas estratégias de disciplina, normatização e controle social passaram a ser criadas pela criminalização das condutas tidas como em desacordo com a moral social estabelecida e legitimada pelo aparato judiciário e policial.

Neste sentido, foi criado um Código de Menores em 1927, para consolidar uma legislação que passou a atuar sobre os chamados "efeitos da ausência de pais" que a partir daquele momento atribuiu ao Estado a tutela da criança.

\section{Referências Bibliográficas}

1 BENJAMIN, Walter. Teses sobre a História. In: Sobre arte, técnica, linguagem e política. Lisboa: Relógio D’Água, 1992.

2 MARCÍLIO, Maria Luíza. História Social da Criança Abandonada. SP: Hucitec, 1998. p. 4.

${ }^{3}$ MARCíliO, Maria Luíza. História Social da Criança Abandonada. SP: Hucitec, 1998. "Três fases caracterizam a assistência à infância abandonada: a caritativa, até meados do século XIX; uma segunda fase de caráter filantrópico, até os anos 1960; e, nas últimas décadas do século XX, a fase do Estado do BemEstar Social." CASTILHO, Eribelto Peres. A Infância silenciada: panorama Histórico e jurídico da questão social da infância no Brasil. p. 2 mimeo. s/d. " Desde a primeira roda dos expostos - que foi uma das instituições brasileiras de mais longa vida, sobrevivendo aos três grandes regimes de nossa História, passando pela fase assistencialista filantrópica em fins do século XIX, a infância, especialmente a pobre e dita abandonada, sempre fora definida de fora, tratada sob o jugo da tutela; como uma realidade social que apesar de existir, não se apresentava como uma questão candente para o Estado."

${ }^{4}$ GALDEMAN, Luciana Mendes. Mulheres para um Império: órfãs e caridade nos recolhimentos da Santa Casa da Misericórdia (Salvador, Rio de Janeiro e Porto- século XVIII). Tese de doutorado. Campinas, UNICAMP. 2005. P.9.

${ }^{5}$ GALDEMAN, Luciana Mendes. Op. Cit.. p.9.

6 “O provedor interino em 1875, Francisco Martins de Almeida, na qualidade de primeiro secretário da Irmandade, nas memórias da Santa Casa que escreveu como introdução ao $1^{\circ}$ relatório dela, correspondente àquele ano, declara que o mais antigo livro de inscrição de irmãos, datado de 26-IX-1680, se refere, no termo de abertura, a um anterior, ao qual sucede." FERREIRA, Tolstoi de Paula. Subsídios para a História da Assistência Social em S. Paulo (Obras sociais no Império). TCC. SP: 1940.p.9. 
${ }^{7}$ Leonor de Avis ou Leonor de Portugal ou Leonor de Lencastre ou Infanta Leonor, ou rainha viúva (1458-
1525). Princesa portuguesa da Casa de Avis, e rainha de Portugal a partir de 1481, pelo casamento com seu
primo João II de Portugal.
8 "O pretexto documental para a identificação da fundação da Misericórdia de Lisboa com a figura de D.
Leonor foi o fato de o ato ter ocorrido numa altura em que o rei de Portugal, irmão da rainha viúva, partira
para Castela, tendo esta assumido o trono. No entanto, esta circunstância adequava-se a lugares comuns
que se prolongam até hoje: aos homens a guerra a política, às mulheres a caridade. Este mito fundacional
espelha uma ideologia de gênero que vigoraria na cultura erudita portuguesa até meados do século XX".
SÂ, Isabel dos Guimarães. As misericórdias portuguesas, séculos XVI a XVIII. RJ: Ed. FGV, 2013. p.
11/12. 9 Disponível em: <http://www.museudesaoroque.com/pt/coleccoes/iluminura/compromisso-damisericordia-de-lisboa.aspx>. Acesso em 12 maio 2015.

${ }^{10}$ FERREIRA, Toltoi de Paula. Subsidios para a História da Assistência Social em S. Paulo (Obras sociais no Império). TCC. SP: 1940.p.5.

${ }^{11}$ RIZZINI, Irene; PILOTTI, Francisco. A Arte de Governar crianças: a história das políticas sociais, da legislação e da assistência à infância no Brasil. $2^{\mathrm{a}}$. Ed. São Paulo: Cortez, 2009. Os autores trabalharam com a assistência pública e privada dada às crianças desde órfãos indígenas e os chegados em navios negreiros.

${ }^{12}$ PUECH, Rezende. A hospitalização através dos tempos. Arquivo da Divisão Técnica, do Departamento de Serviço Social. 1936. P.128. Apud: FERREIRA, Tostoi de Paula. op.cit. p. 2.

${ }^{13}$ PACHECO E SILVA, A.C. Serviços sociais, 1937. Apud: FERREIRA, Toltoi de Paula. op.cit. p. 6. (Diogo Flores de Baldez foi general de uma armada espanhola.)

${ }^{14}$ A Igreja já existia em 1709, foi reedificada em 1717 e demolida em 1888.

${ }^{15}$ Após a transferência do Seminário para outro local, o prédio ficou em ruínas. Reformado mais tarde, o edifício abrigou a Casa da Pólvora e serviu como quartel para tropas militares. Em 1877, a chácara foi transformada em núcleo colonial, o que deu origem ao bairro da Glória. Com os sugestivos nomes de Rua do Cemitério uma vez que por ela se chegava ao antigo Cemitério dos Aflitos (que pode ser localizado atualmente no entorno do "Beco dos Aflitos") e Rua da Santa Casa, porque ali se localizava esse hospital. Disponível em: <http://www.dicionarioderuas.prefeitura. sp.gov.br/PaginasPublicas/ListaLogradouro.aspx>.

${ }^{16}$ NASCIMENTO, Alcileide Cabral do. Da infância em perigo à infância perigosa: as crianças enjeitadas em Recife sob a ótica do poder. (1831-1860). Disponível em: $\langle$ http://www.fazendogenero.ufsc.br/8/sts/ST24/Alcileide_Cabral_do_Nascimento_24.pdf $\rangle$. Acesso em 12 maio 2013.

17 VENÂNCIO, Renato Pinto. Maternidade negada. In: DEL PRIORE, Mary. (org.). História das mulheres no Brasil. São Paulo: Contexto, 1997.p.189.

${ }^{18}$ Disponível em: <https://sampahistorica.wordpress.com/tag/roda-dos-expostos/>. Acesso em 16-3-2015.

${ }^{19}$ MORAES, Maria Candelária V. de. Palestra. SP: Unicastelo, 2 de abril de 2015.

${ }^{20}$ NASCIMENTO, Alcileide Cabral de. A sorte dos enjeitados: o combate ao infanticídio e a institucionalização da assistência às crianças abandonadas no Recife (1789-1832). SP: Annablume: FINEP, 2008.

${ }^{21}$ FERREIRA, Toltoi de Paula. op.cit. p.18.

${ }^{22}$ Separata do Relatório da Irmandade da Santa Casa de Misericórdia de S. Paulo. Apud FERREIRA, Tostoi de Paula. op. cit. p. 22.

${ }^{23}$ MATOS, Maria Izilda Santos de. Do público para o privado: Redefinindo espaços e atividades femininas (1890-1930). Disponível em: 〈www.bibliotecadigital.unicamp.br/document/?down=50920>. Acesso em 20 abr. 2015.

${ }^{24}$ KUHLMANN Jr, Moysés e ROCHA, José Fernando Teles da. Educação no asilo dos expostos da Santa Casa em São Paulo: 1896-1950. Disponível em: <http://www.scielo.br/pdf/cp/v36n129/a 0536129.pdf>. Acesso em 16 março 2015.

${ }^{25}$ RELATÓRIO do Irmão Mordomo dos Expostos. In: Irmandade da Santa Casa de Misericórdia de São Paulo. Relatório [anual], 1936.p.194. São Paulo: 1901/1949. Apud: KUHLMANN Jr, Moysés; ROCHA, José Fernando Teles da. op.cit. p.603.

${ }^{26}$ FERREIRA, Tostoi de Paula. Op. Cit. p. 22.

${ }^{27}$ Lucas Antônio Monteiro de Barros (1767-1851).

${ }^{28}$ Boletim do Departamento de Estatística de São Paulo. №2, fev. 1939. Apud. FERREIRA, Tolstoi de Paula. op. cit. p. 47.

${ }^{29}$ Provedor da Santa Casa. Apud: FERREIRA, Tolstoi de Paula. Op. cit. p.52.

${ }^{30}$ FERREIRA, Tolstoi de Paula. op. cit. p. 48.

${ }^{31}$ FERREIRA, Tolstoi de Paula. Op. cit. p. 48. 


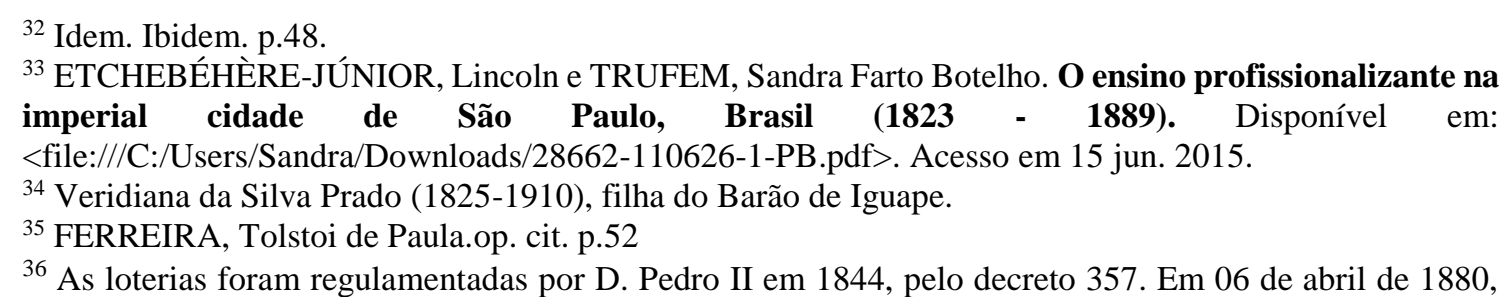
Laurindo Abelardo de Brito, presidente da província de São Paulo, em nome da Assembleia Legislativa de São Paulo, concedeu três loterias para a construção do monumento do Ipiranga, uma delas a correr naquele ano. (LEI n. 49, 06/04/1880). Ainda, antes do sorteio saiu nova lei provincial que dispunha que o valor dos benefícios arrecadados nesta loteria seria investido na educação fundamental (LEI n. 10, 13/02/1881). Por fim, no dia 26 de fevereiro, a loteria sorteou, para o primeiro prêmio, o valor de 1.000:000\$000 (um mil contos). LONER, Beatriz Ana . A Loteria do Ipiranga e os trabalhadores: um sonho de liberdade no final do século XIX História (São Paulo), vol. 33, núm. 1, enero-junio, 2014, pp. 195-233 Universidade Estadual Paulista Júlio de Mesquita Filho São Paulo, Brasil. Disponível em http://www.redalyc.org/pdf/2210/221031471011.pdf. Acesso em 30 nov. 2015.

37 Disponível em: <http://www.santacasasp.org.br/upSrv01/up_publicacoes/4639/5088 3453 MUSEU-HISTORICOS-AS-IRMAS-CHAMBERY.pdf>. Acesso em $1^{\circ}$ jun. 2015.

${ }^{38}$ FERREIRA, Tolstoi de Paula. Op. cit. p.52.

39 Disponível em: <http://www.santacasasp.org.br/upSrv01/up_publicacoes/4639/5088 3453 MUSEU-HISTORICOS-AS-IRMAS-CHAMBERY.pdf>. Acesso em $1^{\circ}$ jun. 2015.

${ }^{40}$ SÁ, Isabel dos Guimarães. As misericórdias portuguesas, séculos XVI a XVIII. RJ: Ed. FGV, 2013. p.8.

${ }^{41}$ CRUZ, Heloisa de Faria. São Paulo em papel e tinta: periodismo e vida urbana, 1890-1915. SP: EDUC/FAPESP, 2000. p.67.

${ }^{42}$ ETCHEBÉHÈRE-JÚNIOR, Lincoln e TRUFEM, Sandra Farto Botelho. O ensino profissionalizante na imperial cidade de São Paulo, Brasil (1823 - 1889). Disponível em: <file://C:/Users/Sandra/Downloads/28662-110626-1-PB.pdf>. Acesso em 15 jun. 2015. p.120.

${ }^{43}$ Relatório Comissão de visitas, 1833. Apud: FERREIRA, Tolstoi de Paula.Op. cit. p.62.

${ }^{44}$ Idem, ibidem. p. 62.

${ }^{45}$ Manuel da Fonseca de Lima e Silva, Barão de Suruí. (1793-1869). Presidente da província de São Paulo entre 1844 e 1847.

${ }^{46}$ LIMA E SILVA. Relatório de Conselho. 1845. Apud: FERREIRA, Tolstoi de Paula. Op. cit. p.64.

${ }^{47} \mathrm{O}$ jornal Paulista, jornal manuscrito, foi o primeiro a circular no interior de São Paulo, em 1823, criado por Antonio Mariano de Azevedo Marques, que foi escrivão da Santa Casa. O Novo Farol foi lançado em 1827, pelo barão, visconde e marquês de Monte Alegre, José da Costa Carvalho. A edição e oficina funcionavam na antiga Rua São José, atual Líbero Badaró. OLIVEIRA, Carlos Eduardo França de. Informação e política nos primórdios da imprensa paulista: o Farol Paulistano (18271831). História,Franca, v.29, n.2, p.295319, Dec. 2010.Availablefrom Disponível em: <http://www.scielo.br/scielo.php?script=sci_arttext\&pid=S010190742010000200017\&lng=en\&nrm=iso> . access on 25 Apr. 2015. Disponível em: <http://dx.doi.org/10.1590/S0101-90742010000200017>

${ }^{48}$ LIMA E SILVA. Relatório de Conselho. 1845. Apud: FERREIRA, Tolstoi de Paula. op. cit. p.64.

${ }^{49}$ LIMA E SILVA. Relatório de Conselho. 1845. Apud: FERREIRA, Tolstoi de Paula. op. cit. p.64.

${ }^{50}$ Idem. Ibidem. p.64.

51 Ver SANTOS, Nilton Pereira dos. A fábrica de ferro S. João de Ipanema: economia e política nas últimas décadas o segundo reinado (1860-1889). 2009. Dissertação (Mestrado em História econômica). Universidade de São Paulo, São Paulo, 2009.

${ }^{52}$ LONDOÑO, Fernando Torres. A origem do conceito Menor. In: DEL PRIORE, Mary (Org). História da criança no Brasil. SP: Ed. Contexto, 1991. p. 130.

${ }^{53}$ José Tomás Nabuco de Araújo Filho (1813-1878). Foi deputado geral, presidente de província, ministro da Justiça e senador do Império do Brasil de 1858 a 1878.

${ }^{54}$ Relatório de Diogo de Mendonça Pinto. 1852. Arquivo do Estado. Apud: FERREIRA, Tolstoi de Paula. op. cit. p.66.

${ }_{55}^{5}$ João Teodoro Xavier de Matos (1828-78). Foi presidente de São Paulo entre 1872-75.

${ }^{56}$ Relatório do presidente da província (1875-78), Joaquim M. Gonçalves de Andrade (1807-1879).

${ }^{57}$ FERREIRA, Tolstoi de Paula. op. cit. p.68.

${ }^{58}$ FONSECA, Sérgio C.. A interiorização da assistência à infância durante a primeira república: de São Paulo a Ribeirão Preto. Educ. rev., Belo Horizonte , v. 28, n. 1, Mar. 2012. Available from 
Disponível em: <http://www.scielo.br/scielo.php?>. accesso em: 3 apr. 2015. Disponível em: $<$ http://dx.doi.org>.

${ }^{59}$ Disponível em: <http://www.anarosa.org.br/?p=texto.php\&c=nossa_historia>. Acesso em: 26 maio 2015.

${ }^{60}$ FERREIRA, Tolstoi de Paula. op. cit. p.70.

${ }^{61}$ Francisco Antônio de Sousa Queirós (1806-1891). Barão de Souza Queiroz. Foi presidente interino da província de São Paulo e senador do Império entre 1849-1891.

${ }^{62}$ Relatório do diretor do Instituto em 1935, João de Toledo. apud: FERREIRA, Tolstoi de Paula. op. cit. p.71.

${ }^{63}$ Ana Rosa de Araújo (1787-1860).

${ }^{64}$ SILVA, Tânia Soares Da. Tecnologia e ciência como ideologia. Revista Projeto História. SP: EDUC, n³4, 2007. p.267. "O pai de Geraldo Horácio de Paula Souza, Antônio Francisco de Paula Souza (18431817), tinha formação em engenharia, Paula Souza era proveniente de uma família da elite cafeeira paulista marcada pela tradição liberal e que assumiu papel importante nos acontecimentos políticos engendrados no século XIX. Seu avô paterno, Francisco de Paula Souza e Mello (1791-1851), casado com D. Maria de Barros Leite (filha de Antônio de Barros Penteado), participara do processo de emancipação política brasileira como deputado das Cortes de Lisboa em 1821 e, com o desenrolar dos acontecimentos, tornouse ainda membro da Assembleia Constituinte, logo dissolvida pelo Imperador D. Pedro I, em 1823. Decorridos dez anos, obteve vaga no Senado, lutando pela implementação de um governo representativo. Seu pai, homônimo Antonio Francisco de Paula Souza (1819- 1866), era médico, formado na Bélgica, fora deputado provincial, deputado geral, ministro da agricultura, elaborando, inclusive, projeto para a extinção da escravidão no Brasil. Sua mãe, Maria Raphaela de Barros (1827-1895) era filha de Antônio Paes de Barros, o primeiro Barão de Piracicaba. Esse pequeno histórico familiar leva à compreensão de que sua origem estava entre os aristocratas paulistas, não causando estranheza esse longo histórico de participação e atuação nos governos; afinal, é sabido que os rumos da política paulista, há muito, eram ditados por esses grupos familiares, detentores do capital com uma organização familiar caracterizada por casamentos endogâmicos como estratégia de aquisição e manutenção de poder."

65 SILVA, Tânia Soares Da. Paula Souza, "arauto da modernidade”. Um estudo da elite paulista (18431917). 2009. Tese (Doutorado em História Social)- PUCSP, 2009. Apresentação.

${ }^{66}$ SILVA, Tânia Soares Da. Idem. Ibidem. p. 18

${ }^{67}$ SILVA, Tânia Soares Da. "Carências": Crianças, mulheres, famílias - As representações na medicina higienista (São Paulo, 1920-1930). Anais ANPUH - XXII SIMPÓSIO NACIONAL DE HISTÓRIA - João Pessoa, 2003. Disponível em: <http://anpuh.org/anais/wp-content/uploads/mp/pdf /ANPUH.S22.666.pdf>. Acesso em 29 jun. 2015.

68 Áries, Philippe. História Social da Criança e da família. Rio de Janeiro, Guanabara, 1981, P. 185.

${ }^{69}$ PASSETTI, Edson. Crianças carentes e políticas públicas. In: DEL PRIORE, Mary (Org.). História das crianças no Brasil. SP: Contexto, 2010. p.347. 